\title{
Synthesis and Insecticidal Activity of Acyclic Nitroethene Compounds Containing a 3-Pyridylmethylamino Group*
}

\author{
Isao Minamida, Koichi Iwanaga, ** Takanori TABUchi, \\ Hideki Uneme, Hirokazu Dantsuji and Tetsuo Okauchi \\ Agricultural Research Laboratories, Agro Division, Takeda Chemical Industries, Ltd., \\ Wadai, Tsukuba 300-42, Japan \\ **Animal Health Research Laboratories, Agro Division, Takeda Chemical Industries, Ltd., \\ Yodogawa-ku, Osaka 532, Japan
}

(Received April 23, 1992; Accepted July 23, 1992)

\begin{abstract}
A series of acyclic nitroethene compounds containing a 3-pyridylmethylamino group in the $\beta$-carbon atom were synthesized, and their insecticidal activities were examined. The compounds into whose 1-carbon atom of 1-(3-pyridylmethyl)amino-2-nitroethene a methylamino (9a-5) or a dimethylamino group (9a-22) was introduced were more effective against Nilaparvata lugens and Laodelphax striatellus than against Nephotettix cincticeps. An introduction of larger alkylamino groups decreased the activity. Successive modifications of the 1-methylamino-1-(3-pyridylmethyl)amino-2-nitroethene revealed that an introduction of a methyl or ethyl group into the nitrogen atom attached to the 3-pyridylmethyl group enhanced the activity. Compounds, such as 1-methylamino-1-[N-methyl(ethyl)- $N$-(3-pyridylmethyl)]amino-2-nitroethene (9b-1,2), exhibited potent activity against not only $N$. lugens and $L$. striatellus but also $N$. cincticeps.
\end{abstract}

\section{INTRODUCTION}

A recent report says that a series of nitrogen containing heterocycles bearing a nitromethylene substituent had potent insecticidal properties (Fig. 1) and that among them tetrahydro-2-nitromethylene- $2 \mathrm{H}$-1,3-thiazine (1) was particularly notable for a broad insecticidal spectrum with high activity against lepidopterous larvae. ${ }^{1)}$ This compound was found unstable under sunlight, however, and efforts to avoid the drawback were undertaken. Thus, the $N$-formyl derivative WL 108477 (2) was chosen as a compound that has both greater photostability and comparable insecticidal activity. ${ }^{2)}$ Later, compounds $3^{3-5}$ and $4{ }^{6)}$ which consist of the same heterocyclic skeleton as was reported in the precedent

* Studies on Acyclic Nitroethene Compounds (Part $1)$. paper $^{1)}$ and a 3-pyridylmethyl side chain in addition, were shown to exhibit exceedingly potent activity.

Incidentally, a random screening in our laboratories picked up acyclic nitromethylenes $(5$ and 6) as potential insecticides active against Nilaparvata lugens (unpublished data). Stimulated by the finding that seemed to contrary to Soloway's conclusion on SAR studies that the heterocyclic skeleton of $\mathbf{1}$ and 2 is essential to the activity, ${ }^{1)}$ we were interested in replacing the heterocyclic skeleton of $\mathbf{1}$ to $\mathbf{4}$ with corresponding acyclic compartments.

This paper describes the synthesis and SAR studies of 1-methylamino-1-[ $N$-methyl- $N$-(3pyridylmethyl)]amino-2-nitroethene (9b-1) in which the pyridylmethylimidazoline portion of 3 was formally replaced by two separated acyclic fragments of this portion, i.e., methylamino and $N$-methyl- $N$-(3-pyridylmethyl)- 


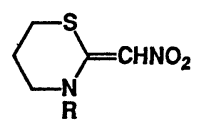

$1 \mathrm{R}=\mathrm{H}$

$2 \mathrm{R}=\mathrm{CHO}$

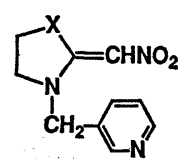

$3 \mathrm{X}=\mathrm{NH}$

$4 X=S$

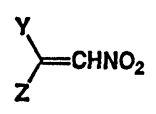

$5 \mathrm{Y}=\mathrm{Z}=$ phenyl

$6 \mathrm{Y}=$ phenyl-S $\mathrm{Z}=\mathrm{H}$
Fig. 1 Nitromethylene compounds.

amino, and its modified derivativés $(\mathbf{9 a}, \mathbf{b}, \mathbf{c})$ listed in Tables 1 to 3 .

\section{MATERIALS AND METHODS}

\section{Synthesis of Compounds}

General: In the procedures of column chromatography, elution was carried out under monitoring by TLC, in which Merck Kieselgel $60 \mathrm{~F}_{254}$ (Art. 5715), a column chromatographic eluent and an UV detector were used.

All solvents were evaporated by roto-evaporation in vacuo. All melting points are uncorrected.

All of the new compounds prepared showed corrective elemental analyses (except oily compounds), NMR charts and IR spectra. NMR spectra were recorded by proton NMR and measured with tetramethylsilane as an internal reference standard with a Varian EM390 (90 $\mathrm{MHz}$ ) spectrometer. All $\delta$ values are expressed in ppm. IR spectra were taken on a Shimadzu IR-435 spectrometer.

All of the compounds except 9a-1, 9a-2, 9a-3, 9a-12, 9c-9 and 9c-10 in Tables 1, 2 and 3 were prepared through three synthetic routes (Fig. 2). By Method A, 1,1-bis(methylthio)-2-nitroethene $(\mathbf{7})^{7)}$ was reacted with $N$-(3pyridylmethyl)- $N$-(substituted)amine ${ }^{8)}$ to give a compound of general formula $\mathbf{8}$, which was then reacted with an amine to thereby give a compound of general formula 9, $1-[N-(3-$ pyridylmethyl) - $N$-(substituted) ]amino- 1 -(substituted)amino-2-nitroethene. Method B reversed the addition order of the reagents by Method A: an amine was added first and then $N$-(3-pyridylmethyl)- $N$-(substituted)amine. By Method C, $N$-(3-pyridylmethyl)- $N$-(substituted)amine was reacted with isothiocyanate to give a thiourea of general formula 11, which was treated with sodium hydride and methyl iodide in tetrahydrofuran (THF) successively. The $S$-methylisothiourea obtained was refluxed in nitromethane to give $9\left(\mathrm{R}^{2}=\mathrm{H}\right) .^{\left.{ }^{9}\right)}$

We have got scme information on the con
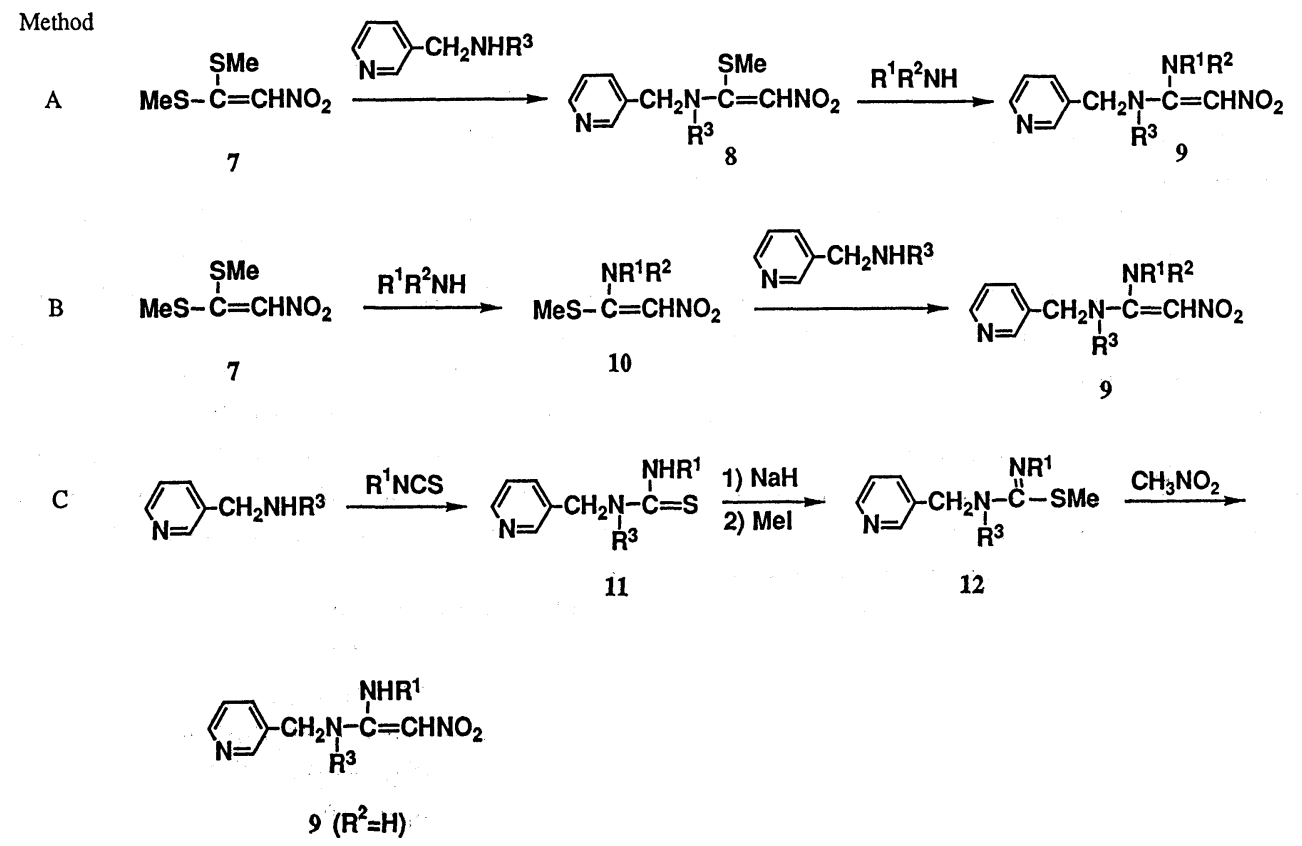

Fig. 2 Syntheses of acyclic nitroethene compounds. 
figuration of the double bond of the compounds described in this and the following articles, which will be referred in the following paper.

Typical examples of synthetic procedures are as follows.

\subsection{Method $A$ \\ 1 - Methylthio - 1 - (3-pyridylmethyl)amino-2- nitroethene (9a-4)}

In $100 \mathrm{ml}$ of EtOH was dissolved $5.0 \mathrm{~g}(0.03$ mol) of 1,1-bis(methylthio)-2-nitroethene ${ }^{7)}$ with heating, and a $3.2 \mathrm{~g}(0.03 \mathrm{~mol})$ solution of 3pyridylmethylamine in $30 \mathrm{ml}$ of $\mathrm{EtOH}$ was added dropwise in three installments at intervals of $20-30 \mathrm{~min}$ while refluxing. The mixture was further refluxed for $2 \mathrm{hr}$ and the EtOH was distilled off in vacuo. The residue was subjected to silica gel column chromatography using $\mathrm{MeOH}-\mathrm{CHCl}_{3}(1: 5)$ as an eluent. The procedure gave $4.0 \mathrm{~g}(59.2 \%)$ of the title compound and $0.5 \mathrm{~g}(5.8 \%)$ of 1,1-bis(3-pyridylmethylamino)-2-nitroethene (9a-12), respectively, each as a white powder. 9a-4: $\mathrm{mp}$ 129$130^{\circ} \mathrm{C}$. Anal. Found: C, 47.97; H, 4.93; N, 18.63, Calcd. for $\mathrm{C}_{9} \mathrm{H}_{11} \mathrm{~N}_{8} \mathrm{O}_{2} \mathrm{~S}: \mathrm{C}, 47.99 ; \mathrm{H}$, $4.92 ; \mathrm{N}, 18.65 \%$. IR $\nu_{\max }^{\text {Nujol }} \mathrm{cm}^{-1}: 1560,1425$, $1360,1350,1330 .{ }^{1} \mathrm{H}$ NMR $\delta_{\mathrm{TMS}}^{\mathrm{CDCl}_{3}} \mathrm{ppm}: 2.48$ $(3 \mathrm{H}, \mathrm{s}), 4.70(2 \mathrm{H}, \mathrm{d}, J=6 \mathrm{~Hz}), 6.62(1 \mathrm{H}, \mathrm{s})$, 7.25-7.45 $(1 \mathrm{H}, \mathrm{m}), 7.6-7.8(1 \mathrm{H}, \mathrm{m}), 8.55-8.7$ $(2 \mathrm{H}, \mathrm{m}), 10.76(1 \mathrm{H}, \mathrm{br}) .9 \mathrm{a}-12$ : $\mathrm{mp} 141-143^{\circ} \mathrm{C}$. Anal. Found: C, 58.68; H, 5.26; N, 24.47, Calcd. for $\mathrm{C}_{14} \mathrm{H}_{15} \mathrm{~N}_{5} \mathrm{O}_{2}: \mathrm{C}, 58.94 ; \mathrm{H}, 5.30 ; \mathrm{N}$, $24.55 \%$. IR $\nu_{\max }^{\text {Nujol }} \mathrm{cm}^{-1}: 3150,1575,1390$. ${ }^{1} \mathrm{H}$ NMR $\delta_{\mathrm{TMS}}^{\mathrm{DMSO}^{\mathrm{MSO}} \mathrm{d}_{6}} \mathrm{ppm}: 4.55(4 \mathrm{H}, \mathrm{d}), 6.52(2 \mathrm{H}$, s), 7.25-7.5 $(1 \mathrm{H}, \mathrm{m}), 7.5-7.8(1 \mathrm{H}, \mathrm{m}), 8.4-8.6$ $(2 \mathrm{H}, \mathrm{m}), 10.26(2 \mathrm{H}$, br s).

1-Methylamino-1-(3-pyridylmethyl)amino-2nitroethene (9a-5)

In $50 \mathrm{ml}$ of $\mathrm{EtOH}$ was dissolved $2.3 \mathrm{~g}(0.01$ mol) of 9a-4 with heating; and a $1.2 \mathrm{~g}(0.015$ mol) solution of $40 \%$ aqueous methylamine in $10 \mathrm{ml}$ of $\mathrm{EtOH}$ was added dropwise over a period of $30 \mathrm{~min}$ while refluxing. The mixture was further refluxed for $2 \mathrm{hr}$ and concentrated. The crystals were collected by filtration and recrystallized from acetonitrile to give $1.6 \mathrm{~g}$ of the title compound as white prisms. $\mathrm{mp} 159-160^{\circ} \mathrm{C}$. Anal. Found: C, 51.67; $\mathrm{H}, 5.86 ; \mathrm{N}, 26.96$, Calcd. for $\mathrm{C}_{9} \mathrm{H}_{12} \mathrm{~N}_{4} \mathrm{O}_{2}$ : C, $51.92 ; \mathrm{H}, 5.81 ; \mathrm{N}, 26.91 \%$ IR $\nu_{\max }^{\mathrm{Nujol}} \mathrm{cm}^{-1}$ : $1620,1580,1390,1215,980 .{ }^{1} \mathrm{H}$ NMR $\delta_{\mathrm{TMS}}^{\mathrm{DMSO}-\mathrm{d}_{6}}$ ppm: $2.86(3 \mathrm{H}, \mathrm{s}), 4.49(2 \mathrm{H}, \mathrm{d}, J=6 \mathrm{~Hz}), 6.46$
$(1 \mathrm{H}, \mathrm{s}), 7.25-7.5(1 \mathrm{H}, \mathrm{m}), 7.6(1 \mathrm{H}, \mathrm{br} \mathrm{s}), 7.6-$ $7.85(1 \mathrm{H}, \mathrm{m}), 8.4-8.7(2 \mathrm{H}, \mathrm{m}), 10(1 \mathrm{H}, \mathrm{br})$.

Compound 9a-4 was reacted with various amines in the same manner as in the preparation of $9 \mathbf{a - 5}$, and the reaction product was purified by recrystallization or silica gel chromatography to give compounds listed in Table 1.

\subsection{Method B \\ 1 - Piperidino - 1 - (3-pyridylmethyl) amino - 2- nitroethene (9a-24) \\ In $20 \mathrm{ml}$ of EtOH was dissolved $1.7 \mathrm{~g}(0.01$} mol) of compound 7 under heating, and $0.9 \mathrm{~g}$ $(0.01 \mathrm{~mol})$ of piperidine dissolved in $10 \mathrm{ml}$ of $\mathrm{EtOH}$ was added dropwise in three portions at $30 \mathrm{~min}$ intervals under reflux. After $2 \mathrm{hr}$ of reflux, the solvent was distilled off, and the residue was chromatographed on a silica gel column and eluted with AcOEt-toluene (2:3). The above procedure yielded $0.8 \mathrm{~g}$ of 1 methylthio-1-piperidino-2-nitroethene as yel$\mathrm{l}_{\text {ow }}$ prisms. $\mathrm{mp} 65-67^{\circ} \mathrm{C}$. Anal. Found: C, 47.61; H, 6.87; N, 13.71, Calcd. for $\mathrm{C}_{8} \mathrm{H}_{14} \mathrm{~N}_{2} \mathrm{O}_{2} \mathrm{~S}:$ C, 47.50; H, 6.98; N, $13.85 \%$. IR $\nu_{\max }^{\text {Nujoi }} \mathrm{cm}^{-1}: 1650,1530,1380,1300,1255$. ${ }^{1} \mathrm{H}$ NMR $\delta_{\mathrm{TMS}}^{\mathrm{CDCl}_{3}} \mathrm{ppm}: 1.6-1.9(6 \mathrm{H}, \mathrm{m}), 2.45$ $(3 \mathrm{H}, \mathrm{s}), 3.4-3.7(4 \mathrm{H}, \mathrm{m}), 6.68(1 \mathrm{H}, \mathrm{s})$.

In $20 \mathrm{ml}$ of EtOH was dissolved $0.8 \mathrm{~g}(0.004$ $\mathrm{mol})$ of 1-methylthio-1-piperidino-2-nitroethene, followed by addition of $0.4 \mathrm{~g}(0.004$ mol) of 3-pyridylmethylamine. The mixture was refluxed for $2 \mathrm{hr}$. The EtOH was distilled off, and the residue was purified by silica gel chromatography to give $0.3 \mathrm{~g}(28.6 \%)$ of the title compound as a pale yellow powder. $\mathrm{mp}$ $106-108^{\circ} \mathrm{C}$. Anal. Found: C, 59.36; H, 6.93; $\mathrm{N}, 21.12$, Calcd. for $\mathrm{C}_{13} \mathrm{H}_{18} \mathrm{~N}_{4} \mathrm{O}_{2}: \mathrm{C}, 59.53 ; \mathrm{H}$, $6.92 ; \mathrm{N}, 21.36 \%$. IR $\nu_{\max }^{\text {Nujol }} \mathrm{cm}^{-1}: 1595,1380$, $1280,1200,975 .{ }^{1} \mathrm{H}$ NMR $\delta_{\mathrm{TMS}}^{\mathrm{CDCl}_{3}} \mathrm{ppm}: 1.66$ (6H, br s), $3.1-3.35(4 \mathrm{H}, \mathrm{m}), 4.50(2 \mathrm{H}, \mathrm{d}, J=$ $6 \mathrm{~Hz}), 6.50(1 \mathrm{H}, \mathrm{s}), 7.31(1 \mathrm{H}, \mathrm{dd}, J=8 \& 5 \mathrm{~Hz})$, $7.73(1 \mathrm{H}, \mathrm{dt}, J=8 \& 1 \mathrm{~Hz}), 8.59(2 \mathrm{H}, \mathrm{m}), 9.80$ ( $1 \mathrm{H}$, br t, $J=6 \mathrm{~Hz}$ ).

The two procedures above were repeated with 1,1-dimethylhydrazine or dimethyl amine instead of piperidine to give compound $\mathbf{9 a - 2 1}$ or $9 \mathrm{c}-8$.
1.3 Method $C$
1 - $[N-$ Ethyl-N - (3-pyridylmethyl $)]$ amino - 1 - methylamino-2-nitroethene (9b-2)
In $50 \mathrm{ml}$ of $\mathrm{Et}_{2} \mathrm{O}$ was dissolved $2.4 \mathrm{~g}$ of $\mathrm{N}$ - 
ethyl- $N$-(3-pyridylmethyl)amine, ${ }^{8)}$ followed by addition of $1.3 \mathrm{~g}$ of methyl isothiocyanate. The mixture was stirred at room temperature for $1 \mathrm{hr}$. The resulting precipitate was collected by filtration, washed with a small amount of $\mathrm{Et}_{2} \mathrm{O}$ and dried to give $3.7 \mathrm{~g}$ of $N$-ethyl- $N^{\prime}$ methyl- $N$-(3-pyridylmethyl)thiourea as white prisms. $\mathrm{mp} 122-123^{\circ} \mathrm{C}$. Anal. Found: C, 57.35; H, 7.31; N, 19.89, Calcd. for $\mathrm{C}_{10} \mathrm{H}_{15} \mathrm{~N}_{3} \mathrm{~S}: \mathrm{C}, 57.38 ; \mathrm{H}, 7.22 ; \mathrm{N}, 20.08 \%$. IR $\nu_{\max }^{\text {Nujol }} \mathrm{cm}^{-1}: 1540,1475,1425,1340,1240,1040$. ${ }^{1} \mathrm{H}$ NMR $\delta_{\mathrm{TMS}}^{\mathrm{CDCl}_{3}} \mathrm{ppm}: 1.16(3 \mathrm{H}, \mathrm{t}, J=7 \mathrm{~Hz})$, $3.16(3 \mathrm{H}, \mathrm{d}, J=5 \mathrm{~Hz}), 3.55(2 \mathrm{H}, \mathrm{q}, J=8 \mathrm{~Hz})$, $5.12(2 \mathrm{H}, \mathrm{s}), 5.95(1 \mathrm{H}, \mathrm{br} \mathrm{s}), 7.27(1 \mathrm{H}, \mathrm{dd}, J=$ $8 \& 5 \mathrm{~Hz}), 7.74(1 \mathrm{H}, \mathrm{dt}, J=8 \& 1 \mathrm{~Hz}), 8.53$ $(2 \mathrm{H}, \mathrm{m})$.

In $30 \mathrm{ml}$ of dry $\mathrm{THF}$ was dissolved $3.1 \mathrm{~g}$ of $N$-ethyl- $N^{\prime}$ - methyl- $N$ - (3-pyridylmethyl)thiourea, followed by addition of $0.6 \mathrm{~g}$ of $60 \%$ sodium hydride. The mixture was stirred at room temperature for $1 \mathrm{hr}$. Then, $2.1 \mathrm{~g}$ of methyl iodide was added dropwise, and the mixture was further stirred for $3 \mathrm{hr}$. The reaction mixture was concentrated, and the residue was diluted with $50 \mathrm{ml}$ of a saturated solution of $\mathrm{NaCl}$ and extracted three times with $50 \mathrm{ml}$ portions of AcOEt. The extracts were pooled and dried over $\mathrm{MgSO}_{4}$. The solvent was then distilled off to give $3.1 \mathrm{~g}$ of $S$, $N^{\prime}$-dimethyl- $N$-ethyl- $N$-(3-pyridylmethyl)isothiourea as a yellow oil. IR $\nu_{\max }^{\text {Neat }} \mathrm{cm}^{-1}: 1600$, $1420,1225,1020,710 .{ }^{1} \mathrm{H}$ NMR $\delta_{\mathrm{TMS}}^{\mathrm{CDCl}_{3}} \mathrm{ppm}$ : $1.06(3 \mathrm{H}, \mathrm{t}, J=7 \mathrm{~Hz}), 2.30(3 \mathrm{H}, \mathrm{s}), 3.23(3 \mathrm{H}$, s), $3.35(2 \mathrm{H}, \mathrm{q}, J=7 \mathrm{~Hz}), 4.53(2 \mathrm{H}, \mathrm{s}), 7.22$ $(1 \mathrm{H}, \mathrm{dd}, J=8 \& 5 \mathrm{~Hz}), 7.59(1 \mathrm{H}, \mathrm{dt}, J=8 \& 1$ $\mathrm{Hz}), 8.50(2 \mathrm{H}, \mathrm{m})$.

To $2.2 \mathrm{~g}$ of $S, N^{\prime}$-dimethyl- $N$-ethyl- $N$-(3-pyridylmethyl)isothiourea was added $10 \mathrm{ml}$ of nitromethane, and the mixture was refluxed for $16 \mathrm{hr}^{9}{ }^{9}$ The reaction mixture was concentrated, and the residue was subjected to silica gel column chromatography using $\mathrm{MeOH}-\mathrm{CHCl}_{3}(1: 5)$ as an eluent to give $1.4 \mathrm{~g}$ of the title compound as a yellow viscous oil. IR $\nu_{\max }^{\text {Neat }} \mathrm{cm}^{-1}: 1600,1420,1360,1210,1010$. ${ }^{1} \mathrm{H}$ NMR $\delta_{\text {TMS }}^{\mathrm{CDCl}_{3}}$ ppm: $1.20(3 \mathrm{H}, \mathrm{t}, J=7 \mathrm{~Hz})$, $3.08(3 \mathrm{H}, \mathrm{d}, J=5 \mathrm{~Hz}), 3.18(2 \mathrm{H}, \mathrm{q}, J=7 \mathrm{~Hz})$, $4.46(2 \mathrm{H}, \mathrm{s}), 6.53(1 \mathrm{H}, \mathrm{s}), 7.33(1 \mathrm{H}, \mathrm{dd}, J=8$ $\& 5 \mathrm{~Hz}), 7.60(1 \mathrm{H}, \mathrm{dt}, J=8 \& 1 \mathrm{~Hz}), 8.57(2 \mathrm{H}$, $\mathrm{m}), 9.86(1 \mathrm{H}, \mathrm{br})$.

\subsection{1 - $[N-$ Methyl-N-(3-pyridylmethyl) $]$ amino-2- nitroethene $(\mathbf{9 a - 1})$}

This compound was prepared according to the Royer's method. ${ }^{10)}$ The mixture of $3.5 \mathrm{~g}$ $(0.05 \mathrm{~mol})$ of ethyl orthformate, $3.0 \mathrm{~g}(0.02$ mol) of nitromethane, $1.2 \mathrm{~g}$ of $N$-methyl- $N$-(3pyridylmethyl)amine and $0.1 \mathrm{~g}$ of $p-\mathrm{TsOH}$ was heated at $120^{\circ} \mathrm{C}$ in an oil bath for $1 \mathrm{hr}$. Volatile materials were evaporated under reduced pressure, and the residue was purified on silica gel column chromatography to give $1.5 \mathrm{~g}$ $(80 \%)$ of the title compound as pale yellow crystals. $\mathrm{mp} 94-95^{\circ} \mathrm{C}$. Anal. Found: C, $55.83 ; \mathrm{H}, 5.62 ; \mathrm{N}, 21.63$, Calcd. for $\mathrm{C}_{9} \mathrm{H}_{11} \mathrm{~N}_{3} \mathrm{O}_{2}$ : C, $55.95 ; \mathrm{H}, 5.74 ; \mathrm{N}, 21.75 \%$. IR $\nu_{\max }^{\text {Nujol }} \mathrm{cm}^{-1}$ : $1620,1320,1250 .{ }^{1} \mathrm{H}$ NMR $\delta_{\text {TMS }}^{\mathrm{CDCl}_{3}}$ ppm: 2.90 $(3 \mathrm{H}$, br s), $4.55(2 \mathrm{H}, \mathrm{br} \mathrm{s}), 6.75(1 \mathrm{H}, \mathrm{d}, J=14$ $\mathrm{Hz}), 7.36(1 \mathrm{H}, \mathrm{dd}, J=8 \& 5 \mathrm{~Hz}), 7.66(1 \mathrm{H}$, br d, $J=8 \mathrm{~Hz}), 8.36(1 \mathrm{H}, \mathrm{d}, J=14 \mathrm{~Hz}), 8.60$ $(1 \mathrm{H}, \mathrm{dd}, J=5 \& 2 \mathrm{~Hz}), 8.68(1 \mathrm{H}, \mathrm{d}, J=1 \mathrm{~Hz})$.

1.5 1-Nitro-2-(3-pyridylmethyl)amino-1-butene $(9 a-2)$

To $6.51 \mathrm{~g}(0.05 \mathrm{~mol})$ of propionic anhydride was added $5.41 \mathrm{~g}$ of 3-pyridylmethylamine under ice-cooling for $20 \mathrm{~min}$, and the mixture was stirred at room temperature for $1 \mathrm{hr}$. Propionic acid produced was removed in vacuo to give $7.81 \mathrm{~g}(95.4 \%)$ of $N$-(3-pyridylmethyl)propionamide as an oil. ${ }^{1} \mathrm{H}$ NMR $\delta_{\mathrm{TMS}}^{\mathrm{CDCl}_{3}} \mathrm{ppm}$ : $1.13(3 \mathrm{H}, \mathrm{t}, J=7.6 \mathrm{~Hz}), 2.24(2 \mathrm{H}, \mathrm{q}, J=7.6$ $\mathrm{Hz}), 4.40(2 \mathrm{H}, \mathrm{d}, J=6.0 \mathrm{~Hz}), 7.10(1 \mathrm{H}$, br s$)$, $7.26(1 \mathrm{H}, \mathrm{dd}, J=8.0 \& 5.0 \mathrm{~Hz}), 7.55-7.75(1 \mathrm{H}$, $\mathrm{m}), 8.4-8.6(2 \mathrm{H}, \mathrm{m})$.

A mixture of $1.64 \mathrm{~g} \quad(0.01 \mathrm{~mol})$ of $\mathrm{N}$-(3pyridylmethyl)propionamide, $6.67 \mathrm{~g}(0.03 \mathrm{~mol})$ of $\mathrm{P}_{2} \mathrm{~S}_{5}$ and $100 \mathrm{ml}$ of toluene was stirred at $70^{\circ} \mathrm{C}$ for $6.5 \mathrm{hr}$. To this mixture were added $80 \mathrm{ml}$ of water and $15.1 \mathrm{~g}(0.18 \mathrm{~mol})$ of $\mathrm{NaHCO}_{3}$ under ice-cooling, followed by stirring at room temperature for $1 \mathrm{hr}$. The organic phase was separated, and the aqueous phase was extracted with $\mathrm{CHCl}_{3}$ after saturation with $\mathrm{NaCl}$. The organic phase combined was dried over $\mathrm{MgSO}_{4}$ and evaporated. The residue was purified on silica gel column chromatography using $\mathrm{MeOH}-\mathrm{CH}_{2} \mathrm{Cl}_{2}(1: 10)$ as an eluent to give $1.45 \mathrm{~g}(80.4 \%)$ of $N$-(3-pyridylmethyl)propionthioamide as an oil. ${ }^{1} \mathrm{H}$ NMR $\delta_{\mathrm{TMS}^{\mathrm{CDCl}}}^{\mathrm{CDC}_{3}}$ ppm: $1.30(3 \mathrm{H}, \mathrm{t}, J=7.6 \mathrm{~Hz}), 2.73(2 \mathrm{H}, \mathrm{q}$, $J=7.6 \mathrm{~Hz}), 4.90(2 \mathrm{H}, \mathrm{d}, J=5.6 \mathrm{~Hz}), 7.30(1 \mathrm{H}$, $\mathrm{dd}, J=8.1 \& 5.1 \mathrm{~Hz}), 7.65-7.85(1 \mathrm{H}, \mathrm{m}), 8.4-$ 
$8.55(2 \mathrm{H}, \mathrm{m}), 8.87$ (1H, br s).

To a solution of $1.45 \mathrm{~g}(0.008 \mathrm{~mol})$ of $\mathrm{N}$-(3pyridylmethyl)propionthioamide in $10 \mathrm{ml}$ of dry THF was added $0.21 \mathrm{~g}(0.009 \mathrm{~mol})$ of $60 \%$ sodium hydride in small portions for $1 \mathrm{~min}$. After stirring for $30 \mathrm{~min}$, a solution $1.26 \mathrm{~g}$ $(0.009 \mathrm{~mol})$ of methyl iodide in $1 \mathrm{ml}$ of dry THF was added dropwise for $10 \mathrm{~min}$, and the mixture was further stirred at room temperature. The mixture was concentrated, and the residue was diluted with $10 \mathrm{ml}$ of water and extracted twice with $\mathrm{CH}_{2} \mathrm{Cl}_{2}$. The solvent was then distilled off to give $1.62 \mathrm{~g}(103.7 \%)$ of $S$ methyl- $N$-(3-pyridylmethyl)propionthioimidate (E, $Z$-mixture) as a crude oil. ${ }^{1} \mathrm{H}$ NMR $\delta_{\mathrm{TMS}}^{\mathrm{CDCl}_{3}} \mathrm{ppm}: 1.1-1.35(3 \mathrm{H}, \mathrm{m}), 2.3-2.75(5 \mathrm{H}$, $\mathrm{m}), 4.53(0.5 \mathrm{H}, \mathrm{s}), 4.60(0.5 \mathrm{H}, \mathrm{s}), 7.15-7.35$ $(1 \mathrm{H}, \mathrm{m}), 7.6-7.85(1 \mathrm{H}, \mathrm{m}), 8.4-8.7(2 \mathrm{H}, \mathrm{m})$.

To $1.62 \mathrm{~g}$ of $S$-methyl- $N$-(3-pyridylmethyl)propionthioimidate was added $15 \mathrm{ml}$ of nitromethane, and the mixture was refluxed for $27.5 \mathrm{hr}$. The reaction mixture was concentrated, and the residue was subjected to silica gel column chromatography using $\mathrm{MeOH}-$ $\mathrm{CH}_{2} \mathrm{Cl}_{2}(1: 10)$ as an eluent to give $1.00 \mathrm{~g}$ $(60 \%)$ of the title compound as a syrup. Anal. Found: C, 57.54; H, 6.22; N, 19.86, Calcd. for $\mathrm{C}_{10} \mathrm{H}_{13} \mathrm{~N}_{3} \mathrm{O}_{2}$ : C, 57.96; $\mathrm{H}, 6.32 ; \mathrm{N}, 20.28 \%$. IR $\nu_{\max }^{\text {Neat }} \mathrm{cm}^{-1}: 3200,1590 .{ }^{1} \mathrm{H}$ NMR $\delta_{\mathrm{TMS}}^{\mathrm{CDCl}_{3}}$ ppm: $1.17(3 \mathrm{H}, \mathrm{t}, J=7.5 \mathrm{~Hz}), 2.38(2 \mathrm{H}, \mathrm{q}$, $J=7.5 \mathrm{~Hz}), \quad 4.68 \quad(2 \mathrm{H}, \mathrm{d}, J=6.6 \mathrm{~Hz}), \quad 6.63$ $(1 \mathrm{H}, \mathrm{s}), \quad 7.38(1 \mathrm{H}, \mathrm{dd}, J=8.1 \& 4.8 \mathrm{~Hz})$, 7.6-7.8 (1H, m), 8.5-8.7 (2H, m), $10.47(1 \mathrm{H}, \mathrm{br} \mathrm{s})$.

1.61 -Methoxy - 1-(3-pyridylmethyl)amino-2nitroethene (9a-3)

In $1 l$ of $\mathrm{MeOH}$ was dissolved $16.5 \mathrm{~g}(0.1$ mol) of 7 with heating on reflux. A solution of $11.0 \mathrm{~g}(0.1 \mathrm{~mol})$ of 3-pyridylmethylamine in $200 \mathrm{ml}$ of $\mathrm{MeOH}$ was added dropwise in four installments at $1 \mathrm{hr}$ intervals. The mixture was further refluxed for $3 \mathrm{hr}$, and the $\mathrm{MeOH}$ was distilled off. The residue was purified by silica gel column chromatography to give $5.9 \mathrm{~g}$ $(28.2 \%)$ of the title compound as white prisms. (In this procedure, compound 9a-4 was also produced as a major product.) $\mathrm{mp} 129-130^{\circ} \mathrm{C}$. Anal. Found: C, 51.38; H, 5.28; N, 19.93, Calcd. for $\mathrm{C}_{9} \mathrm{H}_{11} \mathrm{~N}_{3} \mathrm{O}_{3}: C, 51.67 ; \mathrm{H}, 5.30 ; \mathrm{N}$, $20.09 \%$. IR $\nu_{\max }^{\text {Nujol }} \mathrm{cm}^{-1}: 1610,1425,1370$, $1210,1090 .{ }^{1} \mathrm{H}$ NMR $\delta_{\text {TMS }}^{\mathrm{CDCl}_{3}} \mathrm{ppm}: 3.86(3 \mathrm{H}$, s), $4.63(2 \mathrm{H}, \mathrm{d}, J=6 \mathrm{~Hz}), 6.68(1 \mathrm{H}, \mathrm{s}), 7.30$
(1H, dd, $J=8 \& 5 \mathrm{~Hz}), 7.66(1 \mathrm{H}, \mathrm{dt}, J=8 \&$ $1 \mathrm{~Hz}), 8.59(2 \mathrm{H}, \mathrm{m}), 10.15(1 \mathrm{H}, \mathrm{br})$.

1.71 - $(N$-Formyl-N-methyl)amino-1-[N-methyl$N$ - (3-pyridylmethyl)]amino- 2-nitroethene. $(9 c-9)$

In $10 \mathrm{ml}$ of dry THF was suspended $0.1 \mathrm{~g}$ of petroleum ether-washed $60 \%$ sodium hydride, followed by addition. of $0.51 \mathrm{~g}(0.0023$ mol) of the compound (9b-1): The mixture. was stirred at room temperature overnight, and to it $0.6 \mathrm{~g}$ of formic acetic anhydride was added under ice-cooling. The mixture was stirred at the same temperature for $1 \mathrm{hr}$. The solvent was distilled off, and the residue was diluted with $30 \mathrm{ml}$ of water, neutralized with $\mathrm{NaHCO}_{3}$ and extracted with $\mathrm{CH}_{2} \mathrm{Cl}_{2}(30 \mathrm{ml} \times$ 3). The extract was dried over $\mathrm{MgSO}_{4}$, the $\mathrm{CH}_{2} \mathrm{Cl}_{2}$ was removed by distillation, and the residue was subjected to silica gel column chromatography, elution being carried out with $\mathrm{MeOH}-\mathrm{CHCl}_{3} \quad(1: 5)$. The procedure gave $0.25 \mathrm{~g}$ of the title compound as pale yellow prisms. $\mathrm{mp} 97-98^{\circ} \mathrm{C}$. Anal. Found: C, 52.81; H, 5.58; N, 22.11, Calcd. for $\mathrm{C}_{11} \mathrm{H}_{14} \mathrm{~N}_{4} \mathrm{O}_{3}: \mathrm{C}, 52.79 ; \mathrm{H}, 5.64 ; \mathrm{N}, 22.39 \%$. IR $\nu_{\max }^{\text {Nujol }} \mathrm{cm}^{-1}: 1700,1560,1350,1285,1260,890$. ${ }^{1} \mathrm{H}$ NMR $\delta_{\mathrm{TMS}}^{\mathrm{DMSO}_{6}} \mathrm{ppm}: 2.93(3 \mathrm{H}, \mathrm{s}), 3.03(3 \mathrm{H}$, s), $4.62(2 \mathrm{H}, \mathrm{br}), 6.86(1 \mathrm{H}, \mathrm{s}), 7.42(1 \mathrm{H}, \mathrm{dd}, J=$ $8 \& 5 \mathrm{~Hz}), 7.73(1 \mathrm{H}$, br d, $J=8 \mathrm{~Hz}), 8.25(1 \mathrm{H}$, $\mathrm{s}), 8.55(2 \mathrm{H}, \mathrm{br})$.

\section{$1.81,1-B i s[N-$ methyl $-N$ - (3-pyridylmethyl) $]-$ amino-2-nitroethene $(\mathbf{9 c - 1 0})$}

A mixture of $2.0 \mathrm{~g}(0.012 \mathrm{~mol})$ 1-dimethylamino-1-methylthio-2-nitroethene and $1.5 \mathrm{~g}$ (0.012 mol) $\quad N$-methyl- $N$-(3 - pyridylmethyl)amine was stirred at $120^{\circ} \mathrm{C}$ for $40 \mathrm{~min}$. The reaction mixture was subjected to column chromatography, elution being carried out with

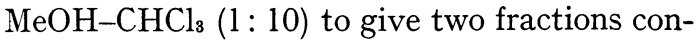
taining compounds $\mathbf{9 c - 8}$ and $\mathbf{9 c - 1 0}$, respectively. One of the fractions was further purified by silica gel column chromatography using $\mathrm{MeOH}-\mathrm{CHCl}_{3} \quad(1: 10)$ and acetone$\mathrm{CHCl}_{3}(2: 1)$ in succession, whereby $0.4 \mathrm{~g}$ of compound $\mathbf{9 c - 8}$ was obtained as pale yellow crystals. The other fraction was also chromatographed on a silica gel column and eluted with $\mathrm{MeOH}-\mathrm{CHCl}_{3} \quad(1: 10)$ and acetone$\mathrm{CHCl}_{3}(2: 1)$ in that order to give $0.35 \mathrm{~g}$ of compound 9c-10 as a yellow oil. ${ }^{1} \mathrm{H}$ NMR $\delta_{\mathrm{TMS}}^{\mathrm{CDCl}_{3}} \mathrm{ppm}: 2.83(6 \mathrm{H}, \mathrm{s}), 4.48(4 \mathrm{H}, \mathrm{s}), 6.52$ 
(1H, s), $7.34(2 \mathrm{H}, \mathrm{dd}, J=8.4 \& 5.1 \mathrm{~Hz}), 7.62$ $(2 \mathrm{H}, \mathrm{dt}, J=8.4 \& 1.5 \mathrm{~Hz}), 8.4-8.8(4 \mathrm{H}, \mathrm{m})$.

\section{Biological Tests}

Each test compound at 500 (200 or 40 ) ppm was sprayed over stems and leaves of rice seedlings in the 2-leaf stage at a rate of $10 \mathrm{ml}$ per paper pot. Water was put in test tubes, and the treated rice seedlings were placed therein. Then 10 (or 20) 3rd-instar larvae of Nilaparvata lugens (Nephotettix cincticeps or Laodelphax striatellus) were released in each tube, which was then capped with an aluminum cap. The test tubes were maintained in an incubator at $25^{\circ} \mathrm{C}$, and dead insects were counted 7 days after release. The $\%$ mortality was calculated using the following formula.

$$
\begin{aligned}
\text { Mortality }(\%)= & (\text { Number of dead insects/ } \\
& \begin{aligned}
\text { Number of insects } \\
\text { released }) \times 100
\end{aligned}
\end{aligned}
$$

\section{RESULTS AND DISCUSSION}

First we prepared a series of 1-(3-pyridylmethyl)amino - 1 - (substituted) - 2 - nitroethenes (9a) by introducing a substituent into the 1-position of 1-(3-pyridylmethyl)amino-2-nitroethene and tested against $N$. lugens, $N$. cincticeps and $L$. striatellus. 1-[ $N$-Methyl- $N$ (3-pyridylmethyl)]amino-2-nitroethene (9a-1) showed weak activity against $N$. lugens probably owing to the methyl group attached to the nitrogen atom bearing a 3-pyridylmethyl group (vide infra). On the other hand, compounds substituted with ethyl (9a-2), methoxy (9a-3) or methylthio (9a-4) did not show activity. Surprisingly, compounds with methylamino (9a-5) and ethylamino (9a-6) showed potent activity. But sterically large alkylamino groups $(\mathbf{9 a - 7}, \mathbf{9}, \mathbf{1 0})$ decreased the activity to less than that of 9a-5 and 9a-6. Anilino (9a-11) and (3-pyridylmethyl)amino (9a-12) also showed a similar effect on the activity. Substituted ethylamino groups behaved differently according to their substituents. Hydroxy (9a-14), dimethoxy (9a-16), $n$-propylthio (9a-18) and trifluoro (9a-19) showed weak or moderate activity against $N$. lugens at 500 ppm, while a methoxy (9a-15) or dimethylamino (9a-17) group on ethyl caused $100 \%$ mortality. Compounds into which a hydrazino group $(\mathbf{9 a - 2 0 , 2 1 )}$ was intro- duced showed $100 \%$ mortality. It is interesting that dimethylamino (9a-22) or pyrrolidino (9a-23) increased the activity, while piperidino (9a-24) or morpholino (9a-25) did not so much. Among all the compounds listed in Table 1, methylamino (9a-5) or dimethylamino (9a-22) substrates seemed most active, when the activity against $L$. striatellus was taken into consideration.

According to the result described we tried to prepare 1-methylamino-1-[N-(3-pyridylmethyl) - $N$-substituted] amino - 2 - nitroethenes (9b) by fixing a 1-methylamino group as position 1's substituent, which was one of the most promising substituents, and by changing the substituent on the nitrogen atom attached to the 3-pyridylmethyl group.

Most compounds shown in Table 2 exhibited potent insecticidal activity against $N$. lugens even at $40 \mathrm{ppm}$. Against L. striatellus these compounds showed $100 \%$ mortality at 200 $\mathrm{ppm}$, but the efficacy at $40 \mathrm{ppm}$ was low except for three compounds $(\mathbf{9 a - 5}, \mathbf{9 b - 1}, \mathbf{2})$. Only two compounds showed $100 \%$ mortality against $N$. cincticeps at $40 \mathrm{ppm}$. These results revealed the susceptibility against these insects decreased in the order of $N$. lugens, $L$. striatellus and $N$. cincticeps.

It is apparent that an introduction of a substituent on the nitrogen atom bearing a 3-pyridylmethyl group enhanced the activity against these insects. Not only alkyl groups (9b-1-4) and substituted alkyl groups (9b-5-7) but also methoxy and dimethylamino groups were effective. Among them relatively smaller alkyl groups (Me and Et) were most effective.

The activity of the reported compounds $\mathbf{3}$ and 4 are also listed in Table 2. Compounds 9b-1 and 9b-2 are superior to $\mathbf{3}$ and $\mathbf{4}$ in the activity against $L$. striatellus and $N$. cincticeps.

According to the results above, we were obliged to reinvestigate structure-activity relationships by fixing a substituent on the nitrogen atom bearing 3-pyridylmethyl as methyl (the smallest alkyl). 1-[N-(3-pyridylmethyl) - $N$ - methyl]amino - 1 - (substituted)amino-2-nitroethenes were prepared and tested against the same insects. Changing the methylamino group into larger alkylamino $(\mathbf{9 c - 2}, \mathbf{3}, \mathbf{5})$, alkenylamino (9c-4), substituted alkylamino 


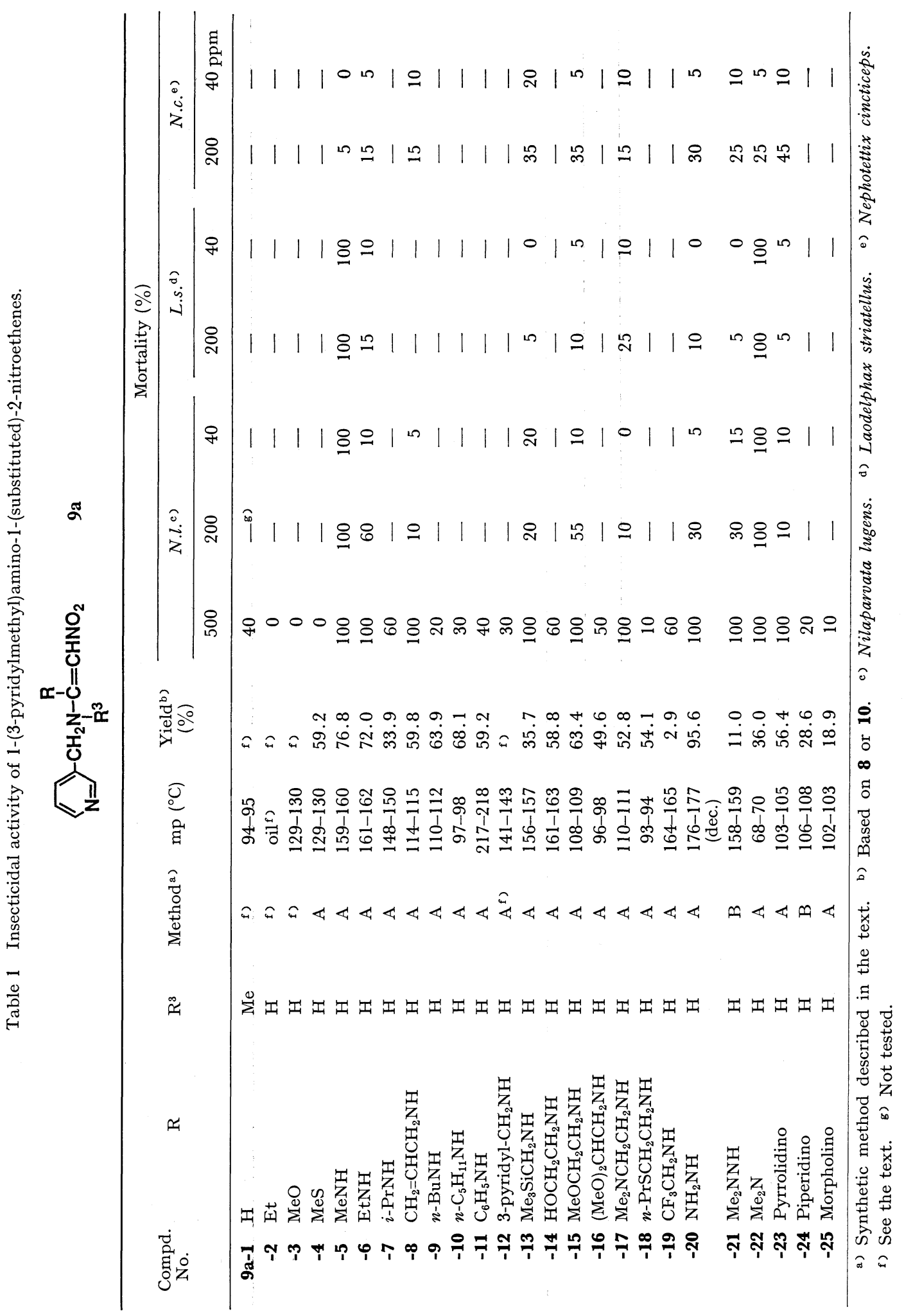




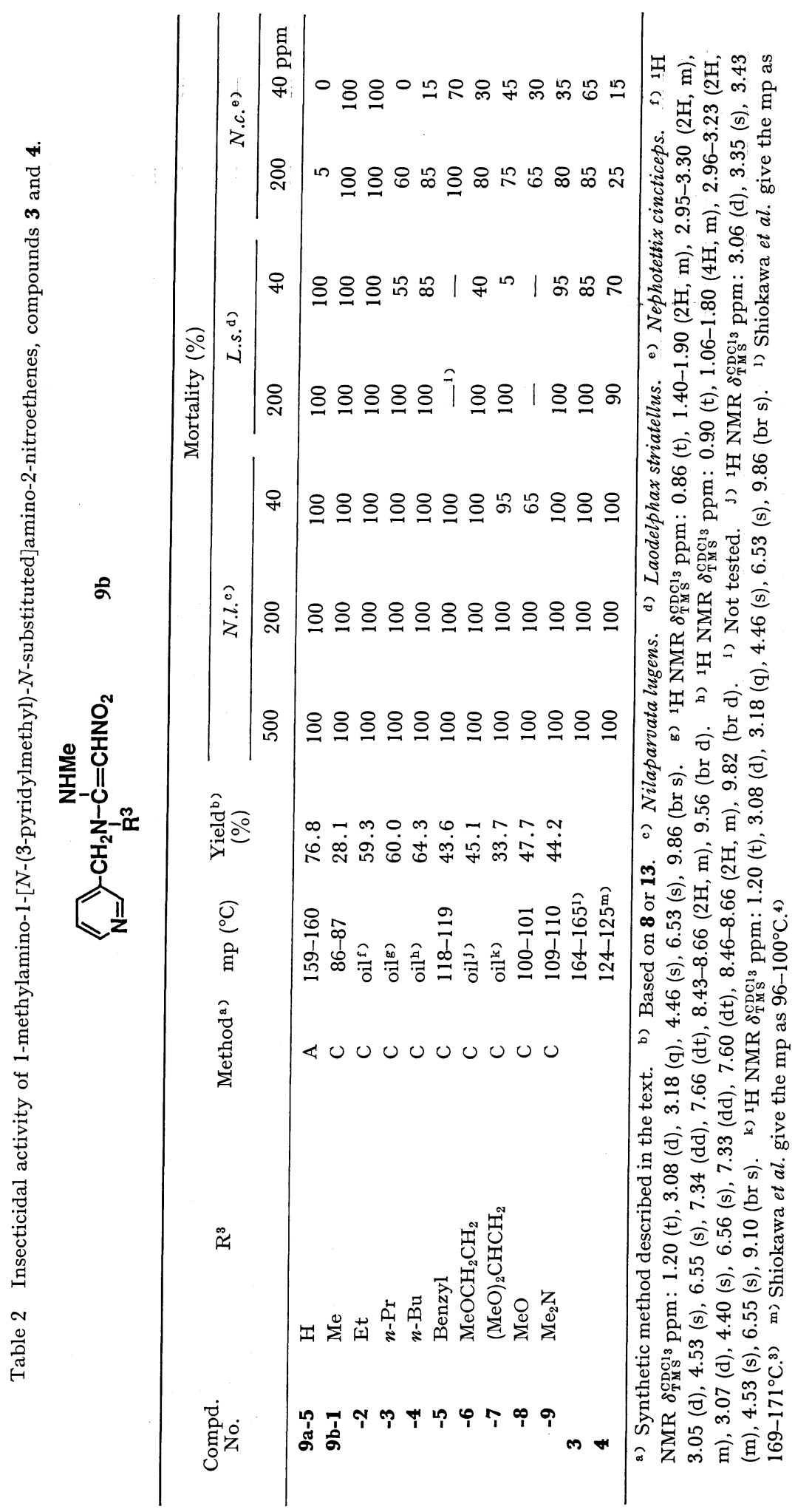




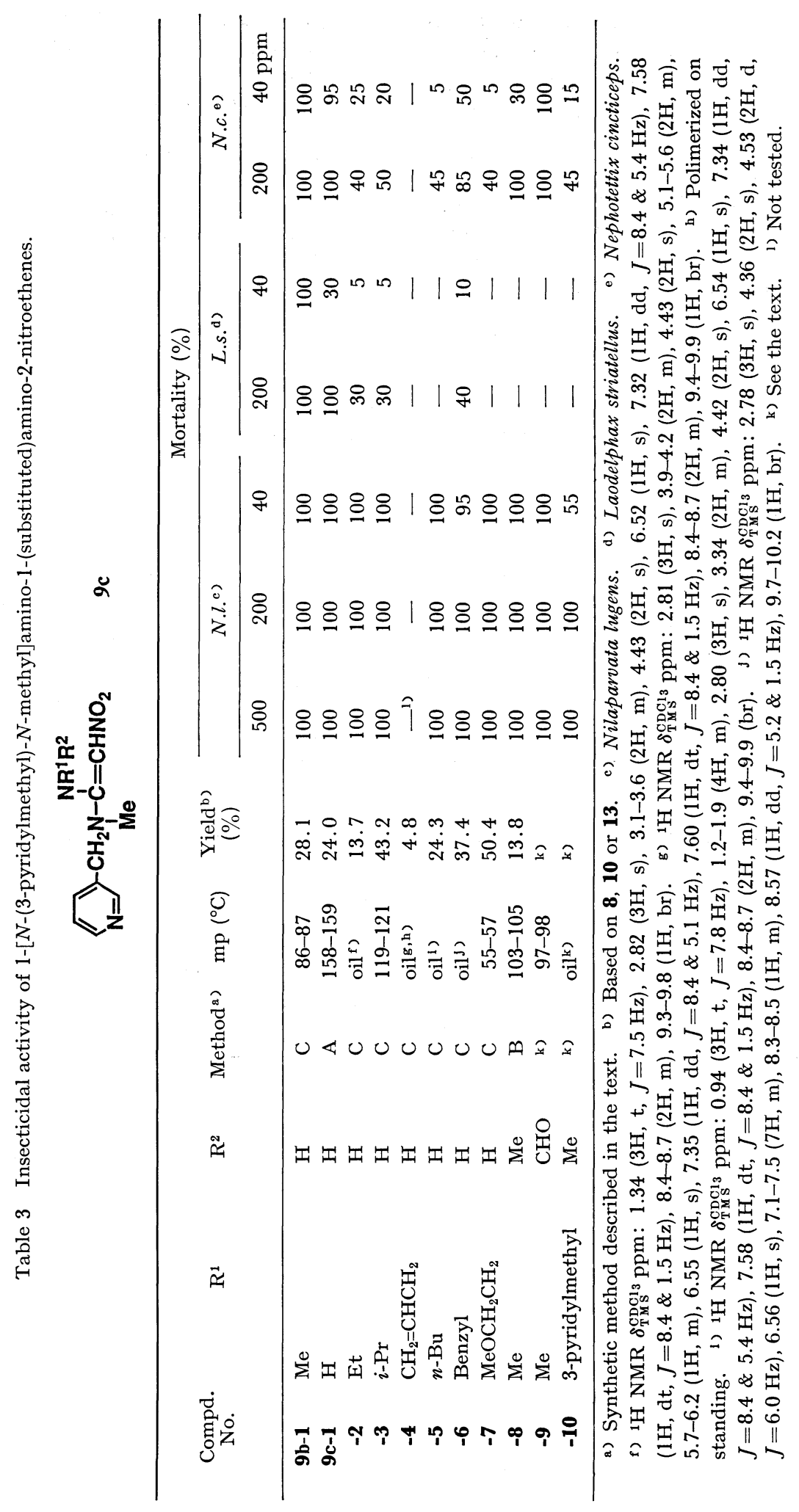


$(\mathbf{9 c - 6}, 7)$ and secondary amino $(9 \mathrm{9c-8}, \mathbf{1 0})$ groups resulted in the decrease of the activity. Only one exception was ( $N$-formyl- $N$-methyl)amino (9c-9), which exhibited similar activity against the pests.

The summary: we prepared a lot of acyclic nitroethene compounds bearing a 3-pyridylmethylamino group and tested the activity against $N$. lugens, $N$. cincticeps and L. striatellus. Among them two (9b-1, 2) or three compounds (9c-9) showed 100\% mortality against these insects at $40 \mathrm{ppm}$.

\section{ACKNOWLEDGMENTS}

The authors wish to thank Drs. Yoshiaki Kohno and Atsuo Akayama for their assistance in the biological test, and helpful and stimulating discussions and suggestions.

\section{REFERENCES}

1) S. B. Soloway, A. C. Henry, W. D. Kollmeyer, W. M. Padgett, J. E. Powell, S. A. Roman, C. H. Tieman, R. A. Corey \& C. A. Horne: "Advances in Pesticide Science," Part 2, Pergamon Press, Oxford, New York, Toronto, Sydney, Paris and Frankfurt, p. 206, 1978

2) M. Harris, R. N. Price, J. Robinson \& T. E. May: 1986 British Crop Protection Conference-Pests and Diseases 2B-4

3) K. Shiokawa, S. Tsuboi, S. Kagabu \& K. Seike (Nihon Tokushu Nouyaku Seizou Co., Ltd.): Jpn. Kokai Tokkyo Koho JP 60-172976 (1985)

4) S. Kagabu, K. Moriya, K. Shibuya, Y. Hattori, S. Tsuboi \& K. Shiokawa: Biosci. Biotech. Biochem. 56, 362 (1992)

5) K. Moriya, K. Shibuya, Y. Hattori, S. Tsuboi, S. Shiokawa \& S. Kagabu: Biosci. Biotech. Biochem. 56, 364 (1992)

6) K. Shiokawa, S. Tsuboi, S. Kagabu \& K. Seike (Nihon Tokushu Nouyaku Seizou Co., Ltd.):
Jpn. Kokai Tokkyo Koho JP 61-178982 (1986)

7) R. Gompper \& H. Schaefer: Chem. Ber. 100, 591 (1967)

8) I. Minamida, K. Iwanaga \& T. Okauchi (Takeda Chemical Industries, Ltd.): Jpn. Kokai Tokkyo Koho JP 2-171 (1990)

9) S. Rajappa, R. Sreenivasan, B. G. Advani, R. H. Summerville \& R. Hoffmann: Indian J. Chem. 15B, 297 (1977)

10) M. Faulques, L. Rene \& R. Royer: Synthesis 1982, 260

\section{要約}

\section{3-ピリジルメチルアミノ基を有する非環状ニト ロエテン化合物の合成と殺虫活性*}

南田 勲, 岩永幸一, 田㴊学典

采女英樹，壇辻寬和，岡内哲夫

$\beta$-炭素上に 3-ピリジルメチルアミノ基を有する非環 状ニトロエテン化合物を合成し，その殺虫活性を検討し た. 1-(3-ピリジルメチル)アミノー2-ニトロエテンの 1 位炭素にメチルアミノ基をたはジメチルアミノ基を導入 した化合物はトビイロウンカ，ヒメトビウンカに対する 活性は強かったが，ツマグロヨコバイに対する活性は弱 かった．またより大きいアルキルアミノ基を導入すると 活性は減少した. 1 位をメチルアミノ基に固定し, 1-メ チルアミノー1-(3-ピリジルメチル)アミノー2-ニトロエ テンの 3-ピリジルメチル基の結合した窒素原子を次に 修飾した．この窒素原子にメチル基あるいはエチル基を 導入すると殺虫活性は上昇し，1-メチルアミノ-1- $[N-$

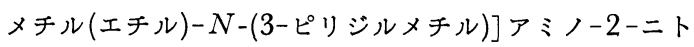
ロエテン $(9 \mathrm{~b}-1,2)$ はトビイロウンカ, ヒメトビウンカ だけでなく，ツマグロヨコバイに対しても強い活性を示 した。

* 非環状ニトロエテン化合物の研究（第 1 報） 